\title{
Current Approaches for Management of Postpenetrating Keratoplasty Astigmatism
}

\author{
Sepehr Feizi and Mohammad Zare \\ Ophthalmic Research Center and Department of Ophthalmology, Labbafinejad Medical Center, \\ Shahid Beheshti University of Medical Sciences, Tehran 16666, Iran \\ Correspondence should be addressed to Mohammad Zare, drzarea@yahoo.com
}

Received 29 March 2011; Accepted 6 June 2011

Academic Editor: Edward Manche

Copyright (c) 2011 S. Feizi and M. Zare. This is an open access article distributed under the Creative Commons Attribution License, which permits unrestricted use, distribution, and reproduction in any medium, provided the original work is properly cited.

A successful corneal graft requires both clarity and an acceptable refraction. A clear corneal graft may be an optical failure if high astigmatism limits visual acuity. Intraoperative measures to reduce postkeratoplasty astigmatism include round and central trephination of cornea with an adequate size, appropriate sutures with evenly distributed tension, and perfect graft-host apposition. Suture manipulation has been described for minimising early postoperative astigmatism. If significant astigmatism remains after suture removal, which cannot be corrected by optical means, then further surgical procedures containing relaxing incisions, compression sutures, laser refractive surgery, insertion of intrastromal corneal ring segments, wedge resection, and toric intraocular lens implantation can be performed. When astigmatism cannot be reduced using one or more abovementioned approaches, repeat penetrating keratoplasty should inevitably be considered. However, none of these techniques has emerged as an ideal one, and corneal surgeons may require combining two or more approaches to exploit the maximum advantages.

\section{Introduction}

Penetrating keratoplasty (PK) has emerged as a relatively safe means of restoring vision in corneal opacities and irregularities. PK is generally considered to be a successful procedure, and the graft clarity rate in keratoconic patients can be $97 \%$ [1]. However, PK breaches the structural and immunological integrity of the eye, which can result in traumatic wound dehiscence and endothelial graft rejection. Another option is lamellar keratoplasty which can avoid not only endothelial rejection but also most complications encountered during open sky surgery such as anterior synechiae, expulsive hemorrhage, and endophthalmitis. Recent improvements in surgical instruments and introduction of new techniques of maximum depth of corneal dissection namely layer-by-layer manual dissection, Melles air-guided deep stromal dissection, Anwar big-bubble technique, or automated anterior lamellar keratoplasty have made deep anterior lamellar keratoplasty an acceptable alternative to PK [2].

Astigmatism is the most common cause of suboptimal vision after corneal transplantation despite a clear corneal graft $[3,4]$. Based on several studies, $15-31 \%$ of patients undergoing PK may develop postoperative astigmatism greater than 5 diopters (D) $[1,5-7]$. The astigmatism can be irregular with associated higher-order aberrations that can ultimately limit the vision obtained and add to patient's inability to wear standard optical correction [8]. This explains why visual acuity in $10-20 \%$ of PK cases cannot be corrected satisfactorily by spectacles or contact lenses [9-11].

Factors influencing the amount of astigmatism after PK include the severity of the underlying disorder (e.g., keratoconus), oval or eccentric trephination, [12] graft size and donor-recipient disparity, [13] corneal thickness mismatch between the donor and recipient, [14] a poor suturing technique, [14-18] and time of suture removal or adjustment [15-18].

Commonly practiced techniques to reduce post-PK astigmatism consist of postoperative suture manipulation including running suture tension adjustment and selective interrupted suture removal, $[15,19-22]$ optical correction consisting of spectacles and contact lenses, [23] relaxing incisions, $[4,11]$ compression sutures, $[4,24]$ a combination 
of relaxing incisions and compression sutures (augmented relaxing incisions), [25-27] laser refractive surgery, [28-34] insertion of intrastromal corneal ring segments, [35] wedge resection, $[10,36-40]$ toric phakic intraocular lenses, [41$43]$ and finally regrafting [44].

\section{General Considerations}

The corneal graft-host junction typically heals by 1 year after transplantation and corneal surface stability is achieved from 3 to 4 months after complete suture removal. However, this period can significantly vary due to patient's age, general health status (diabetes mellitus and collagen vascular disorders), and use of topical and systemic immunosuppressive medications. Given that, any surgical intervention for postPK astigmatism should be postponed at least from 3 to 4 months after complete suture removal. Previous rejection episodes should be noted and the patient should be stable on minimal immunosuppressive agents [45]. Prior to any surgical intervention, a comprehensive ophthalmic examination including uncorrected (UCVA) and best spectaclecorrected visual acuity (BSCVA) should be performed. Slitlamp biomicroscopy is used to evaluate graft size, centration, and clarity as well as detect any areas of haze or neovascularization. Attention should be paid to the graft-host interface for quality of apposition (override or underride) and stability of surgical wound.

Astigmatism should be evaluated through a combination of manifest (and sometimes cycloplegic) refraction, keratometry, corneal topography, and occasionally wavefront analysis. Central and peripheral pachymetry is required when laser or incisional refractive surgery is anticipated, respectively.

\section{Calculation of Surgically-Induced Refractive Change}

Astigmatism is described with magnitude and direction. As a result, simple arithmetic calculations comparing pre- and postoperative astigmatism magnitudes ignore any change in the astigmatism orientation and can be misleading because it does not identify the separate errors of magnitude and axis. Surgically induced change in astigmatism which can be calculated by two basic methods of analyzing vectors, namely graphic and trigonometrical, take into account the vectorial change in astigmatism including its magnitude and direction. The examination of astigmatism outcomes by vector analysis has been described by a number of authors in various ways [46-48].

\section{Intraoperative Measurements}

During PK, attention should be paid to some critical points if a low postoperative astigmatism is to be obtained. A perfect surgical technique, including round and central trephination of recipient and donor which should be large enough to cover abnormal areas (such as thin cornea in keratoconus), is required to achieve an acceptable refractive outcome postoperatively. Additionally, appropriate sutures with evenly distributed tension and apposition make sure that patients experience a low amount of astigmatism. Suturing technique including interrupted, single or double running, and combined interrupted and running are comparable in terms of postoperative graft astigmatism as long as timely suture adjustment and/or removal are performed [49].

\section{Suture Tension Adjustment and Selective Suture Removal}

After PK, sutures should be kept for at least one year unless complications such as cheese-wiring, loosening, and vascularization develop. During this period, astigmatism $>4 \mathrm{D}$ can be reduced by suture manipulation consisting of selective interrupted suture removal and tension adjustment of running sutures. Use of interrupted or combined running and interrupted sutures allows for the selective removal of interrupted ones, with the goal of reducing astigmatism. Successful visual rehabilitation therefore depends partially on accurate identification of the tight-interrupted sutures. Refraction and keratometry can be used to determine which sutures have to be removed. Identifying the steep and flat corneal meridians $90^{\circ}$ apart, however, refraction and manual keratometry could be misleading in patients undergoing keratoplasty in whom nonorthogonal and irregular astigmatism is common. Computerized corneal topography has the advantage of mapping subtle corneal power changes accurately over the entire optical zone and beyond allowing identification of steep meridians that can be attributed to specific sutures $[22,50]$. In the interrupted suturing technique, selective suture removal can start as early as 2 months after PK, provided that the neighboring sutures are not to be removed at least 6 months postoperatively. That is because removal of adjacent sutures within this period is more likely to make the wound unstable than removal of alternate or nonadjacent sutures. After initial suture removal, nonadjacent sutures can be removed at an interval of 4-6 weeks, as seen necessary $[20,21]$. It is better to remove only a single suture at a time as it yields better results in terms of astigmatism as compared to multiple-suture removal at one time [15, 22].

If a combined running and interrupted suturing technique is used, then many of the interrupted sutures can be safely removed as early as 1 week postoperatively with minimal risk of wound problems.

Tension adjustment of running sutures should be done after 2 to 4 weeks when graft edema disappears but within 2 months when the reparative response does not completely take place at the graft-host interface. Every episode of suture removal has the added risk of infection and/or rejection, and appropriate antibiotic and steroid cover are essential.

When a small amount of astigmatism is achieved through suture manipulation, the sutures are left in as long as possible, until they fray or break $[19,44]$.

\section{Optical Corrections}

Spectacles and rigid gas-permeable (RGP) contact lenses are the simplest method of addressing postoperative refractive 
error even when sutures are still in place. However, the use of glasses may not be possible when a significant amount of astigmatic anisometropia is present. RGP contact lenses, which may be effective in $80 \%$ of cases, often provide superior visual acuity and are frequently required in eyes with moderate to severe astigmatism [23]. The main concern of post-PK contact lens fitting is to minimize trauma to the corneal graft. Typically, large diameter $(9.5-12.0 \mathrm{~mm})$ RGP lenses are prescribed to minimize bearing on the graft-host interface and provide improved stability and centration. A large optic zone size will help to minimize glare. When fitting the post-PK patient, a careful evaluation of the central and peripheral cornea is warranted and best done with corneal topography. The corneal shape resulting from the graft procedure predicts which type of contact lens will be the most effective. A prolate shape has a steeper central area and a flatter periphery. An aspheric, biaspheric, or in cases of a very steep graft a keratoconic lens design would be appropriate for a prolate shape. An oblate pattern is a plateau shape and the donor cornea is flatter than the host cornea. A reverse geometry lens with a flatter center and a steeper secondary curve would be suitable for this type of graft. Mixed prolate/oblate corneal shapes present with a flat side and a steep side with symmetrical astigmatism and can be corrected using a bitoric RGP lens. Asymmetrical astigmatism can be described as a combination of patterns with an irregular or possibly distorted cornea. Depending on the amount and location of irregularity, a large standard tricurve, aspheric, or keratoconic design may be appropriate $[51,52]$.

Unfortunately, contact lenses are often difficult to fit, strictly dependent on a patient's tolerance and lifestyle, and may induce peripheral corneal neovascularization leading to graft rejection and failure. Furthermore, many patients (the elderly in particular) are unable to handle or maintain contact lenses [53,54].

\section{Incisional Keratotomy}

Relaxing incisions with or without counter-quadrant compression sutures is an effective, simple, and safe method to reduce high-post-PK astigmatism [11, 26, 27, 55-59]. Patients with keratometric astigmatism $>4.0 \mathrm{D}$ after complete suture removal can be considered for this procedure. Under topical anesthesia and direct visual inspection, relaxing incisions are made down to Descemet membrane usually on the both sides of the steepest meridian with an arc length of 45 degrees to 90 degrees. The site and extension of relaxing incisions are determined on the basis of corneal topography [60]. The effect of these relaxing incisions is monitored intraoperatively with a hand-held keratoscope. If an adequate effect is not obtained through relaxing incisions alone, interrupted 10-0 nylon compression sutures are added to achieve overcorrection of astigmatism in the opposite meridian (90 degrees away) to reverse the axis of astigmatism as apparent by the keratoscopic mires. Postoperatively, selective suture removal is initiated 3-4 weeks after the procedure until an acceptable amount of astigmatism is achieved. Thereafter, further suture removal is postponed until no suture effect is observed.

The site of relaxing incision can be either in the donor cornea or at the graft-host interface. Incisions in the recipient cornea are not recommended as it is believed that the scarring at the graft-host junction changes the biomechanical state of the cornea. The keratoplasty wound is supposed to form a new limbus, blocking the effect of relaxing incisions in the recipient cornea [61].

Using subtraction or vector analysis to calculate the reduction in astigmatism, a wide range of corrections between $3.4 \mathrm{D}$ and $9.7 \mathrm{D}$ has been reported by this approach $[11,26$, $27,55-59]$. However, this procedure has a high incidence of recurrence of astigmatism and low predictability [10]. Other disadvantages include overcorrection, corneal perforation, wound dehiscence, and prolonged instability of corneal topography [10, 40,62]. Additionally, there are no standardized nomograms to correlate the amount of keratometric astigmatism with the extension of incisions, and those developed for congenital astigmatism cannot be applied to the correction of post-PK astigmatism.

In an attempt to increase the safety and efficacy, femtosecond laser (FSL) technology has been recently introduced in the clinical practice. Nubile et al. [63] confirmed the feasibility and efficacy of astigmatic keratotomy using FSL to treat postkeratoplasty astigmatism. They reported paired FSL incisions located on the steepest corneal meridian, peripherally inside the graft, at the intended depth of $90 \%$ of the local stromal thickness, provided a significant reduction of preoperative subjective astigmatism from $7.16 \pm 3.07 \mathrm{D}$ to $2.23 \pm 1.55 \mathrm{D}$ which remained stable for several months. Kumar et al. [64] reported that IntraLase-enabled astigmatic keratectomy was effective in reducing high post-PK astigmatism and significantly improved UCVA and BSCVA, while refraction became stable between 3 and 6 months postoperatively. Adverse effects encountered in these two studies, however, were overcorrection necessitating early resuturing, and a higher rate of allograft rejection successfully treated with topical corticosteroids [63, 64]. Additionally, the procedure adversely affected higher-order aberrations which was similar to what was reported after manual astigmatic keratectomy in PK corneas [63-65].

In the majority of cases, relaxing incisions with or without counter-quadrant compression sutures are the only procedure performed at the time. However, it is sometimes combined with other interventions such as cataract extraction and intraocular lens (IOLs) implantation or phakic IOL implantation to simultaneously address lens opacity or high refractive error, respectively. To choose the accurate power of IOLs in such cases, it is important to know the exact effect of the intervention on graft steepness. Any possible hyperopic or myopic shift caused by such interventions should be compensated for the power of IOLs to achieve a reasonable refractive outcome after combined surgeries. Previously, a myopic shift of up to $1.5 \mathrm{D}$ has been reported after relaxing incisions $[9,10,27]$ which should be taken into account for IOL power calculation during combined approaches. 


\section{Laser Refractive Surgery}

Excimer laser photoablation techniques are capable of treating astigmatism as well as coexisting spherical refractive error after corneal transplantation. The use of LASIK after PK was first reported by Arenas and Maglione in 1997 [29]. PRK has also been used to correct refractive errors after PK [30-34]. A unique advantage of PRK is the lack of flap-related complications. However, PRK in post-PK patients is less predictable and less effective than for naturally occurring astigmatism [32]. Other complications associated with Post-PK PRK are increased incidences of irregular astigmatism, significant regression, and late-developing corneal haze [32, 66, 67]. There has been a decrease in the incidence of post-PRK haze in recent years because of improved laser, the intraoperative use of mitomycin-C, and better postoperative care [68]. Additionally, the introduction of custom PRK wavefront ablation technique can further refine the outcomes of laser surgery in this complex group of eyes [69].

As compared to PRK, LASIK has several advantages including fast visual rehabilitation, decreased stromal scarring, minimal regression, and the ability to treat a greater amount of refractive errors [29, 66, 70-72]. Factors that may influence the outcome of astigmatism treatment by LASIK other than the wound-healing process are the position of the hinge in relation to the location of the visual axis, flap diameter relative to the $\mathrm{PK}$ donor button diameter, and flap thickness $[61,73]$. In addition, corneal graft thickness and the amount of refractive error may limit the efficacy of the procedure [74]. The disadvantages include limited correction of astigmatism and potential for flap complications such as epithelial ingrowth, button hole, free or incomplete flaps $[29,74]$ as well as an increased risk of photoablationinduced graft rejection and diminished flap adhesion [7577]. However, endothelial cell loss after LASIK is no higher than the normal postkeratoplasty decline $[78,79]$. Furthermore, because the lamellar flap is larger than the corneal graft, thinning of the graft-host interface occurs after the microkeratome cut which can lead to wound dehiscence [78, 80, 81].

To improve outcomes, some authors propose performing the LASIK procedure in 2 steps (flap creation first followed by laser ablation 8 to 12 weeks later) because of a hinged lamellar keratotomy effect [82, 83]. Lamellar cuts may induce substantial changes in the graft shape as corneal stress caused by irregularities in wound shape, and wound healing is removed from the graft center after creating a flap resulting in changes of up to $4.0 \mathrm{D}$ of astigmatism [83].

\section{Intrastromal Corneal Ring Segments}

In a small group of patients with post-PK astigmatism, Kerarings were implanted which significantly reduced mean keratometry values and significantly improved corneal topography and uncorrected visual acuity [35]. However, several complications were encountered during and after Kerarings implantation including small dehiscence of grafthost interface during stroma tunnel dissection, an inflam- matory infiltrate around the segment immediately after operation, stromal channel vascularization leading to ring explanation, and night halos [35].

\section{Wedge Resection}

In this procedure, a wedge of corneal tissue including the recipient and/or donor cornea is excised from the flatter corneal meridian to correct high astigmatism (usually higher than 10.0 D) after PK [36-40]. The length and width of a wedge resection and its proximity to the central cornea determine the amount of astigmatism to be corrected. Various nomograms have been used. In general, approximately from 0.05 to $0.1 \mathrm{~mm}$ of tissue is removed for every $1.0 \mathrm{D}$ of preoperative astigmatism [37-39]. Suture tightness and removal are important factors. The sutures should be tight enough to approximate the borders of the wound. Usually 6 to 8 sutures are placed on each wound and kept for 3 to 6 months. An initial overcorrection is the rule and should not induce premature suture removal. The procedure results in an increase in overall graft curvature, hence a myopic shift will generally be encountered $[37,40]$.

One surgical drawback of corneal wedge resection is the difficulty in manually excising the exact amount of tissue in width and depth, which may account for the low predictability of the technique [37]. Additionally, microperforations can occur during the course of the procedure which renders the eye soft and prevents completion of the procedure.

Recently, FSL has been used as a safe and effective alternative to the manual technique to perform a corneal wedge resection [84]. This device can allow easier, more controlled, and more precise excision of tissue in width, length, and depth and reduce the risk of corneal perforation. Using this technique, Ghanem and Azar [84] reported a reduction of $14.5 \mathrm{D}$ in postkeratoplasty astigmatism.

\section{Intraocular Lens Implantation}

In cases of high astigmatism after penetrating keratoplasty, implantation of a toric IOL offers a promising alternative to arcuate keratotomies with or without compression sutures. These kinds of IOLs are used during cataract extraction or in phakic eyes. Cataract extraction with implantation of toric intraocular lenses (tIOL) is a new surgical option for correction of residual astigmatism following penetrating keratoplasty with only minimal direct manipulation of the graft. Viestenz et al. [41] reported that the refractive cylinder could be reduced from $7.0 \pm 2.6 \mathrm{D}$ to $1.63 \pm 1.5 \mathrm{D}$ after surgery. They recommended, however, regular and symmetric corneal topography be essential for successful implantation of tIOL [41].

In phakic eyes, Artisan toric intraocular lens was implanted to correct refractive errors after keratoplasty $[42,43]$. The use of the Artisan toric IOL, with a power range of 7.5 D of cylinder and $-20.5 \mathrm{D}$ of myopia to $+12.0 \mathrm{D}$ of hyperopia, provides a wide field for correction of postkeratoplasty astigmatism and ametropia. Tahzib et al. [43] reported the spherical equivalent was reduced from $-3.19 \pm 4.31 \mathrm{D}$ (range, 
+5.5 to $-14.25 \mathrm{D}$ ) preoperatively to $-1.03 \pm 1.20 \mathrm{D}$ (range, +1.0 to $-5.25 \mathrm{D}$ ) postoperatively and refractive cylinder from $-7.06 \pm 2.01 \mathrm{D}$ to $-2.00 \pm 1.53 \mathrm{D}$ at the last followup [43] After 36 months, the postoperative mean endothelial cell loss was $30.4 \% \pm 32.0 \%$ [ 43 ] which is significantly higher than the reported cell loss in other studies of the natural endothelial cell loss after penetrating keratoplasty (between $4.2 \%$ and $7.8 \%)[85,86]$ and higher than that in studies of Artisan lens implantation for correction of high myopia (between $0.78 \%$ and 9.1\%) [87-89]. Probably, the higher cell loss is explained by the increased vulnerability of the corneal graft endothelium, which usually has low cell densities and may cause a higher rate of endothelial cell loss. Other potential complications of the Artisan toric IOL for the correction of postkeratoplasty astigmatism include loss of $>2$ lines of BSCVA, surgically-induced astigmatism by implantation of the rigid PMMA IOL through a $5.5-$ to $6.0-\mathrm{mm}$ incision, reversible immunologic rejection, and irreversible corneal decompensation $[42,43]$.

\section{Repeat Keratoplasty}

This intervention should be considered as the last option for treating intractable high/irregular postkeratoplasty astigmatism in clear corneal grafts when other aforementioned interventions fail. Reporting a small group of patients who underwent repeat PK using the 193-nm Zeiss-Meditec MEL60 excimer laser and employing double running sutures, Szentmáry et al. [44] observed a significant decrease in central graft power and an improvement in astigmatism with sutures in place. However, astigmatism increased significantly after second suture removal. They concluded with all-sutures-in, BSCVA and astigmatism improve significantly after repeat PK for high/irregular astigmatism. However, to prevent significant increase in astigmatism, final suture removal should be postponed as long as possible in such eyes.

\section{Conclusion}

Now, we have a large armamentarium of refractive surgery to correct postkeratoplasty astigmatism. However, none of them appear as a perfect option, and corneal surgeons should tailor a specific plan, on the basis of patient's needs and clinical situations, to take advantages of each intervention. For example, when the astigmatism is too high to be corrected with excimer laser alone, it can be reduced by relaxing incisions to a level which is treatable by PRK or LASIK. Similarly, a combination of relaxing incisions followed by IOL implantation or IOL implantation followed by excimer laser can be considered to achieve a refractive outcome very close to emmetropia.

\section{Conflict of Interests}

There is no financial interest in any of the materials mentioned in this study.

\section{References}

[1] M. A. Javadi, B. F. Motlagh, M. R. Jafarinasab et al., "Outcomes of penetrating keratoplasty in keratoconus," Cornea, vol. 24, no. 8, pp. 941-946, 2005.

[2] F. Karimian and S. Feizi, "Deep anterior lamellar keratoplasty: indications, surgical techniques and complications," Middle East African Journal of Ophthalmology, vol. 17, no. 1, pp. 2837, 2010.

[3] K. A. Williams, N. B. Hornsby, C. M. Bartlett et al., "Report from the Australian corneal graft registry," Tech. Rep., Snap Printing, Adelaide, Australia, 2004.

[4] N. C. Price and A. D. Steele, "The correction of postkeratoplasty astigmatism.," Eye, vol. 1, part 5, pp. 562-566, 1987.

[5] R. C. Troutman and M. A. Lawless, "Penetrating keratoplasty for keratoconus," Cornea, vol. 6, no. 4, pp. 298-305, 1987.

[6] K. A. Williams, D. Roder, A. Esterman, S. M. Muehlberg, and D. J. Coster, "Factors predictive of corneal graft survival: report from the Australian corneal graft registry," Ophthalmology, vol. 99, no. 3, pp. 403-414, 1992.

[7] R. J. Olson, M. Pingree, R. Ridges, M. L. Lundergan, C. Alldredge Jr., and T. E. Clinch, "Penetrating keratoplasty for keratoconus: a long-term review of results and complications," Journal of Cataract and Refractive Surgery, vol. 26, no. 7, pp. 987-991, 2000.

[8] M. S. Rajan, D. P. S. O'Brart, P. Patel, M. G. Falcon, and J. Marshall, "Topography-guided customized laser-assisted subepithelial keratectomy for the treatment of postkeratoplasty astigmatism," Journal of Cataract and Refractive Surgery, vol. 32, no. 6, pp. 949-957, 2006.

[9] R. C. Troutman and C. Swinger, "Relaxing incision for control of postoperative astigmatism following keratoplasty," Ophthalmic Surgery, vol. 11, no. 2, pp. 117-120, 1980.

[10] J. H. Krachmer and R. E. Fenzl, "Surgical correction of high postkeratoplasty astigmatism. Relaxing incisions vs wedge resection," Archives of Ophthalmology, vol. 98, no. 8, pp. 14001402, 1980.

[11] G. W. Lavery, R. L. Lindstrom, L. A. Hofer, and D. J. Doughman, "The surgical management of corneal astigmatism after penetrating keratoplasty,” Ophthalmic Surgery, vol. 16, no. 3, pp. 165-169, 1985.

[12] K. L. Cohen, R. E. Holman, N. K. Tripoli, and L. K. Kupper, "Effect of trephine tilt on corneal button dimensions," American Journal of Ophthalmology, vol. 101, no. 6, pp. 722$725,1986$.

[13] S. V. Woodford, "Control of postkeratoplasty astigmatism," in Corneal Surgery: Theory, Technique and Tissue, F. S. Brightbill, Ed., pp. 431-440, Mosby, New York, NY, USA, 3rd edition, 1999.

[14] C. H. Karabatsas, S. D. Cook, F. C. Figueiredo, J. P. Diamond, and D. L. Easty, "Combined interrupted and continuous versus single continuous adjustable suturing in penetrating keratoplasty: a prospective, randomized study of induced astigmatism during the first postoperative year," Ophthalmology, vol. 105, no. 11, pp. 1991-1998, 1998.

[15] L. L. Burk, G. O. Waring III, B. Radjee, and R. D. Stulting, "The effect of selective suture removal on astigmatism following penetrating keratoplasty," Ophthalmic Surgery, vol. 19, no. 12, pp. 849-854, 1988.

[16] D. C. Musch, R. F. Meyer, and A. Sugar, "The effect of removing running sutures on astigmatism after penetrating keratoplasty," Archives of Ophthalmology, vol. 106, no. 4, pp. 488-492, 1988. 
[17] L. Spadea, F. Cifariello, G. Bianco, and E. Balestrazzi, "Longterm results of penetrating keratoplasty using a single or double running suture technique," Graefe's Archive for Clinical and Experimental Ophthalmology, vol. 240, no. 5, pp. 415-419, 2002.

[18] J. I. McNeill and V. J. Aaen, "Long-term results of single continuous suture adjustment to reduce penetrating keratoplasty astigmatism," Cornea, vol. 18, no. 1, pp. 19-24, 1999.

[19] E. A. Davis, D. T. Azar, F. M. Jakobs, and W. J. Stark, "Refractive and keratometric results after the triple procedure: experience with early and late suture removal," Ophthalmology, vol. 105, no. 4, pp. 624-630, 1998.

[20] P. S. Binder, "The effect of suture removal on postkeratoplasty astigmatism," American Journal of Ophthalmology, vol. 105, no. 6, pp. 637-645, 1988.

[21] W. S. Van Meter, J. R. Gussler, K. D. Soloman, and T. O. Wood, "Postkeratoplasty astigmatism control: single continuous suture adjustment versus selective interrupted suture removal," Ophthalmology, vol. 98, no. 2, pp. 177-183, 1991.

[22] S. Strelow, E. J. Cohen, K. G. Leavitt, and P. R. Laibson, "Corneal topography for selective suture removal after penetrating keratoplasty," American Journal of Ophthalmology, vol. 112, no. 6, pp. 657-665, 1991.

[23] F. W. Price Jr., W. E. Whitson, and R. G. Marks, "Progression of visual acuity after penetrating keratoplasty," Ophthalmology, vol. 98, no. 8, pp. 1177-1185, 1991.

[24] M. B. Limberg, S. A. Dingeldein, M. T. Green, S. D. Klyce, M. S. Insler, and H. E. Kaufman, "Corneal compression sutures for the reduction of astigmatism after penetrating keratoplasty," American Journal of Ophthalmology, vol. 108, no. 1, pp. 36-42, 1989.

[25] M. R. Mandel, M. B. Shapiro, and J. H. Krachmer, "Relaxing incisions with augmentation sutures for the correction of postkeratoplasty astigmatism," American Journal of Ophthalmology, vol. 103, no. 3, part 2, pp. 441-447, 1987.

[26] D. L. McCartney, C. E. Whitney, W. J. Stark, S. K. Wong, and D. A. Bernitsky, "Refractive keratoplasty for disabling astigmatism after penetrating keratoplasty," Archives of Ophthalmology, vol. 105, no. 7, pp. 954-957, 1987.

[27] M. A. Javadi, S. Feizi, S. Yazdani, A. Sharifi, and H. Sajjadi, "Outcomes of augmented relaxing incisions for postpenetrating keratoplasty astigmatism in keratoconus," Cornea, vol. 28, no. 3, pp. 280-284, 2009.

[28] M. A. Malecha and E. J. Holland, "Correction of myopia and astigmatism after penetrating keratoplasty with laser in situ keratomileusis," Cornea, vol. 21, no. 6, pp. 564-569, 2002.

[29] E. Arenas and A. Maglione, "Laser in situ keratomileusis for astigmatism and myopia after penetrating keratoplasty," Journal of Refractive Surgery, vol. 13, no. 1, pp. 27-32, 1997.

[30] K. Yoshida, Y. Tazawa, and T. T. Demong, "Refractive results of post penetrating keratoplasty photorefractive keratectomy," Ophthalmic Surgery and Lasers, vol. 30, no. 5, pp. 354-359, 1999.

[31] P. J. McDonnell, H. Moreira, T. N. Clapham, J. D’Arcy, and C. R. Munnerlyn, "Photorefractive keratectomy for astigmatism: initial clinical results," Archives of Ophthalmology, vol. 109, no. 10, pp. 1370-1373, 1991.

[32] K. Bilgihan, S. C. Ozdek, F. Akata, and B. Hasanreisoğlu, "Photorefractive keratectomy for post-penetrating keratoplasty myopia and astigmatism," Journal of Cataract and Refractive Surgery, vol. 26, no. 11, pp. 1590-1595, 2000.

[33] M. E. John, E. Martines, T. Cvintal et al., "Photorefractive keratectomy following penetrating keratoplasty," Journal of
Refractive and Corneal Surgery, vol. 10, no. 2, pp. S206-S210, 1994.

[34] R. K. Maloney, W. K. Chan, R. Steinert, P. Hersh, and M. O'Connell, "A multicenter trial of photorefractive keratectomy for residual myopia after previous ocular surgery. Summit therapeutic refractive study group," Ophthalmology, vol. 102, no. 7, pp. 1042-1052, 1995.

[35] P. Arriola-Villalobos, D. Díaz-Valle, J. L. Güell et al., "Intrastromal corneal ring segment implantation for high astigmatism after penetrating keratoplasty," Journal of Cataract and Refractive Surgery, vol. 35, no. 11, pp. 1878-1884, 2009.

[36] M. Lugo, E. D. Donnenfeld, and J. J. Arentsen, "Corneal wedge resection for high astigmatism following penetrating keratoplasty," Ophthalmic Surgery, vol. 18, no. 9, pp. 650-653, 1987.

[37] J. Frucht-Pery, "Wedge resection for postkeratoplasty astigmatism," Ophthalmic Surgery, vol. 24, no. 8, pp. 516-518, 1993.

[38] R. C. Troutman, "Corneal wedge resections and relaxing incisions for postkeratoplasty astigmatism," International Ophthalmology Clinics, vol. 23, no. 4, pp. 161-168, 1983.

[39] H. S. Geggel, "Limbal wedge resection at the time of intraocular lens surgery for reducing postkeratoplasty astigmatism," Ophthalmic Surgery, vol. 21, no. 2, pp. 102-108, 1990.

[40] R. L. Lindstrom and T. D. Lindquist, "Surgical correction of postoperative astigmatism," Cornea, vol. 7, no. 2, pp. 138-148, 1988.

[41] A. Viestenz, M. Küchle, B. Seitz, and A. Langenbucher, "Toric intraocular lenses for correction of persistent corneal astigmatism after penetrating keratoplasty," Ophthalmologe, vol. 102, no. 2, pp. 148-152, 2005.

[42] R. M. M. A. Nuijts, K. A. Abhilakh Missier, V. A. Nabar, and W. J. Japing, "Artisan toric lens implantation for correction of postkeratoplasty astigmatism," Ophthalmology, vol. 111, no. 6, pp. 1086-1094, 2004.

[43] N. G. Tahzib, Y. Y. Y. Cheng, and R. M. M. A. Nuijts, “Threeyear follow-up analysis of Artisan toric lens implantation for correction of postkeratoplasty ametropia in phakic and pseudophakic eyes," Ophthalmology, vol. 113, no. 6, pp. 976984, 2006.

[44] N. Szentmáry, B. Seitz, A. Langenbucher, and G. O. H. Naumann, "Repeat keratoplasty for correction of high or irregular postkeratoplasty astigmatism in clear corneal grafts," American Journal of Ophthalmology, vol. 139, no. 5, pp. 826830, 2005.

[45] N. Preschel, D. R. Hardten, and R. L. Lindstrom, "LASIK after penetrating keratoplasty," International Ophthalmology Clinics, vol. 40, no. 3, pp. 111-123, 2000.

[46] N. Alpins, "Astigmatism analysis by the Alpins method," Journal of Cataract and Refractive Surgery, vol. 27, no. 1, pp. 31-49, 2001.

[47] G. C. Tabin, N. Alpins, G. F. Aldred, C. A. McCarty, and H. R. Taylor, "Astigmatic change 1 year after excimer laser treatment of myopia and myopic astigmatism," Journal of cataract and refractive surgery, vol. 22, no. 7, pp. 924-930, 1996.

[48] J. T. Holladay, T. V. Cravy, and D. D. Koch, "Calculating the surgically induced refractive change following ocular surgery," Journal of Cataract and Refractive Surgery, vol. 18, no. 5, pp. 429-443, 1992.

[49] M. A. Javadi, M. Naderi, M. Zare, A. Jenaban, H. M. Rabei, and A. Anissian, "Comparison of the effect of three suturing techniques on postkeratoplasty astigmatism in keratoconus," Cornea, vol. 25, no. 9, pp. 1029-1033, 2006. 
[50] S. E. Wilson and S. D. Klyce, "Quantitative descriptors of corneal topography. A clinical study," Archives of Ophthalmology, vol. 109, no. 3, pp. 349-353, 1991.

[51] P. Caroline and L. Zilge, "Postsurgical correction with contact lens fitting following penetrating keratoplasty," in Clinical Contact Lens Practice, E. Bennett and B. Weissman, Eds., pp. 113, 1994.

[52] A. Langenbucher, B. Seitz, and G. O. H. Naumann, "Threeaxis ellipsoidal fitting of videokeratoscopic height data after penetrating keratoplasty," Current Eye Research, vol. 24, no. 6, pp. 422-429, 2002.

[53] D. R. Hardten and R. L. Lindstrom, "Surgical correction of refractive errors after penetrating keratoplasty," International Ophthalmology Clinics, vol. 37, no. 1, pp. 1-35, 1997.

[54] D. H. Chang and D. R. Hardten, "Refractive surgery after corneal transplantation," Current Opinion in Ophthalmology, vol. 16, no. 4, pp. 251-255, 2005.

[55] S. M. Chang, C. Y. Su, and C. P. Lin, "Correction of astigmatism after penetrating keratoplasty by relaxing incision with compression suture: a comparison between the guiding effect of photokeratoscope and of computer-assisted videokeratography," Cornea, vol. 22, no. 5, pp. 393-398, 2003.

[56] A. Fronterrè and G. P. Portesani, "Relaxing incisions for postkeratoplasty astigmatism," Cornea, vol. 10, no. 4, pp. 305-311, 1991.

[57] C. M. Kirkness, L. A. Ficker, A. D. Steele, and N. S. C. Rice, "Refractive surgery for graft-induced astigmatism after penetrating keratoplasty for keratoconus," Ophthalmology, vol. 98, no. 12, pp. 1786-1792, 1991.

[58] M. Claesson and W. J. Armitage, "Astigmatism and the impact of relaxing incisions after penetrating keratoplasty," Journal of Refractive Surgery, vol. 23, no. 3, pp. 284-290, 2007.

[59] H. S. Geggel, "Arcuate relaxing incisions guided by corneal topography for postkeratoplasty astigmatism: vector and topographic analysis," Cornea, vol. 25, no. 5, pp. 545-557, 2006.

[60] M. R. Wilkins, J. S. Mehta, and D. F. P. Larkin, "Standardized arcuate keratotomy for postkeratoplasty astigmatism," Journal of Cataract and Refractive Surgery, vol. 31, no. 2, pp. 297-301, 2005.

[61] C. Roberts, "The cornea is not a piece of plastic," Journal of Refractive Surgery, vol. 16, no. 4, pp. 407-413, 2000.

[62] R. J. Duffey, V. N. Jain, H. Tchah, R. F. Hofmann, and R. L. Lindstrom, "Paired arcuate keratotomy. A surgical approach to mixed and myopic astigmatism," Archives of Ophthalmology, vol. 106, no. 8, pp. 1130-1135, 1988.

[63] M. Nubile, P. Carpineto, M. Lanzini et al., "Femtosecond laser arcuate keratotomy for the correction of high astigmatism after keratoplasty," Ophthalmology, vol. 116, no. 6, pp. 10831092, 2009.

[64] N. L. Kumar, I. Kaiserman, R. Shehadeh-Mashor, W. Sansanayudh, R. Ritenour, and D. S. Rootman, "IntraLaseenabled astigmatic keratotomy for post-keratoplasty astigmatism: on-axis vector analysis," Ophthalmology, vol. 117, no. 6, pp. 1228-1235, 2010.

[65] I. Bahar, E. Levinger, I. Kaiserman, W. Sansanayudh, and D. S. Rootman, "IntraLase-enabled astigmatic keratotomy for postkeratoplasty astigmatism," American Journal of Ophthalmology, vol. 146, no. 6, pp. 897-904, 2008.

[66] D. R. Lazzaro, D. H. Haight, S. C. Belmont, R. P. Gibralter, I. M. Aslanides, and M. G. Odrich, "Excimer laser keratectomy for astigmatism occurring after penetrating keratoplasty," Ophthalmology, vol. 103, no. 3, pp. 458-464, 1996.
[67] M. Campos, L. Hertzog, J. Garbus, M. Lee, and P. J. McDonnell, "Photorefractive keratectomy for severe postkeratoplasty astigmatism," American Journal of Ophthalmology, vol. 114, no. 4, pp. 429-436, 1992.

[68] F. Carones, L. Vigo, E. Scandola, and L. Vacchini, "Evaluation of the prophylactic use of mitomycin- $\mathrm{C}$ to inhibit haze formation after photorefractive keratectomy," Journal of Cataract and Refractive Surgery, vol. 28, no. 12, pp. 2088-2095, 2002.

[69] E. Pedrotti, A. Sbabo, and G. Marchini, "Customized transepithelial photorefractive keratectomy for iatrogenic ametropia after penetrating or deep lamellar keratoplasty," Journal of Cataract and Refractive Surgery, vol. 32, no. 8, pp. 1288-1291, 2006.

[70] A. Parisi, D. J. Salchow, M. E. Zirm, and C. Stieldorf, "Laser in situ keratomileusis after automated lamellar keratoplasty and penetrating keratoplasty," Journal of Cataract and Refractive Surgery, vol. 23, no. 7, pp. 1114-1118, 1997.

[71] E. D. Donnenfeld, H. S. Kornstein, A. Amin et al., "Laser in situ keratomileusis for correction of myopia and astigmatism after penetrating keratoplasty," Ophthalmology, vol. 106, no. 10, pp. 1966-1974, 1999.

[72] A. S. Forseto, C. M. Francesconi, R. A. Nosé, and W. Nosé, "Laser in situ keratomileusis to correct refractive errors after keratoplasty," Journal of Cataract and Refractive Surgery, vol. 25, no. 4, pp. 479-485, 1999.

[73] S. K. Webber, M. A. Lawless, G. L. Sutton, and C. M. Rogers, "LASIK for post penetrating keratoplasty astigmatism and myopia," British Journal of Ophthalmology, vol. 83, no. 9, pp. 1013-1018, 1999.

[74] S. Kwitko, D. R. Marinho, S. Rymer, and S. R. Filho, "Laser in situ keratomileusis after penetrating keratoplasty," Journal of Cataract and Refractive Surgery, vol. 27, no. 3, pp. 374-379, 2001.

[75] R. J. Epstein and J. B. Robin, "Corneal graft rejection episode after excimer laser phototherapeutic keratectomy," Archives of Ophthalmology, vol. 112, no. 2, p. 157, 1994.

[76] P. S. Hersh, A. J. Jordan, and M. Mayers, "Corneal graft rejection episode after excimer laser phototherapeutic keratectomy," Archives of Ophthalmology, vol. 111, no. 6, pp. 735-736, 1993.

[77] T. A. Kovoor, E. Mohamed, H. D. Cavanagh, and R. W. Bowman, "Outcomes of LASIK and PRK in previous penetrating corneal transplant recipients," Eye and Contact Lens, vol. 35, no. 5, pp. 242-245, 2009.

[78] C. Barraquer and T. Rodriguez-Barraquer, "Five-year results of laser in-situ keratomileusis (LASIK) after penetrating keratoplasty," Cornea, vol. 23, no. 3, pp. 243-248, 2004.

[79] D. R. Hardten, A. Chittcharus, and R. L. Lindstrom, "Long term analysis of LASIK for the correction of refractive errors after penetrating keratoplasty," Cornea, vol. 23, no. 5, pp. 479489, 2004.

[80] C. C. Chan and D. S. Rootman, "Corneal lamellar flap retraction after LASIK following penetrating keratoplasty," Cornea, vol. 23, no. 6, pp. 643-646, 2004.

[81] T. M. Ranchod and S. D. McLeod, "Wound dehiscence in a patient with keratoconus after penetrating keratoplasty and LASIK," Archives of Ophthalmology, vol. 122, no. 6, pp. 920921, 2004.

[82] J. L. Alió, J. Javaloy, A. A. Osman, V. Galvis, A. Tello, and H. E. Haroun, "Laser in situ keratomileusis to correct postkeratoplasty astigmatism: 1-step versus 2-step procedure," Journal of Cataract and Refractive Surgery, vol. 30, no. 11, pp. 2303-2310, 2004. 
[83] M. Busin, R. C. Arffa, L. Zambianchi, G. Lamberti, and A. Sebastiani, "Effect of hinged lamellar keratotomy on postkeratoplasty eyes," Ophthalmology, vol. 108, no. 10, pp. 18451851, 2001.

[84] R. C. Ghanem and D. T. Azar, "Femtosecond-laser arcuate wedge-shaped resection to correct high residual astigmatism after penetrating keratoplasty," Journal of Cataract and Refractive Surgery, vol. 32, no. 9, pp. 1415-1419, 2006.

[85] W. M. Bourne, D. O. Hodge, and L. R. Nelson, "Corneal endothelium five years after transplantation," American Journal of Ophthalmology, vol. 118, no. 2, pp. 185-196, 1994.

[86] W. M. Bourne, L. R. Nelson, and D. O. Hodge, "Continued endothelial cell loss ten years after lens implantation," Ophthalmology, vol. 101, no. 6, pp. 1014-1022, 1994.

[87] F. J. Malecaze, H. Hulin, P. Bierer et al., "A randomized paired eye comparison of two techniques for treating moderately high myopia: LASIK and artisan phakic lens," Ophthalmology, vol. 109, no. 9, pp. 1622-1630, 2002.

[88] M. Pop and Y. Payette, "Initial results of endothelial cell counts after artisan lens for phakic eyes: an evaluation of the United States food and drug administration ophtec study," Ophthalmology, vol. 111, no. 2, pp. 309-317, 2004.

[89] M. Landesz, J. G. F. Worst, and G. van Rij, "Long-term results of correction of high myopia with an iris claw phakic intraocular lens," Journal of Refractive Surgery, vol. 16, no. 3, pp. 310-316, 2000. 


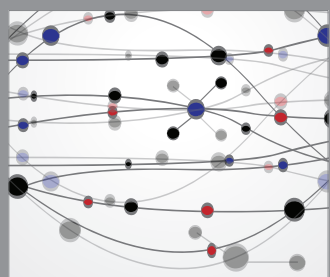

The Scientific World Journal
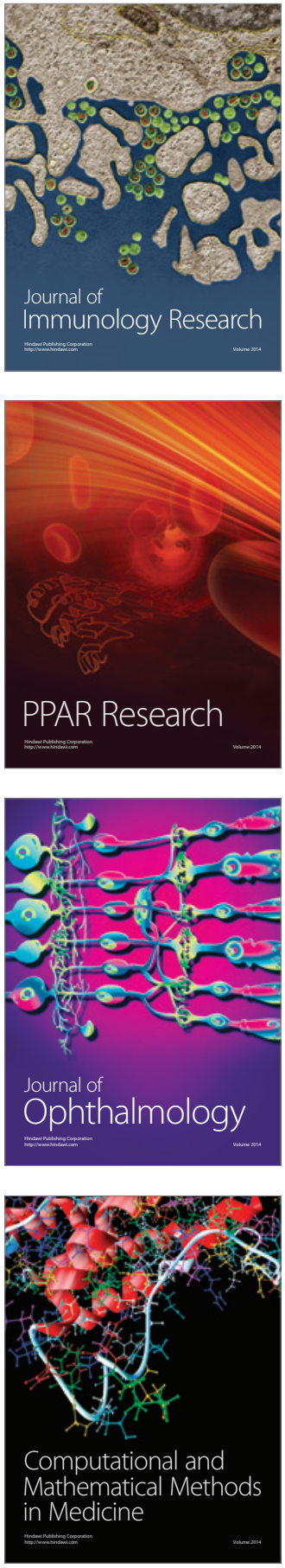

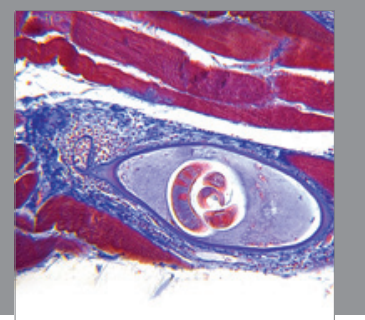

Gastroenterology

Research and Practice
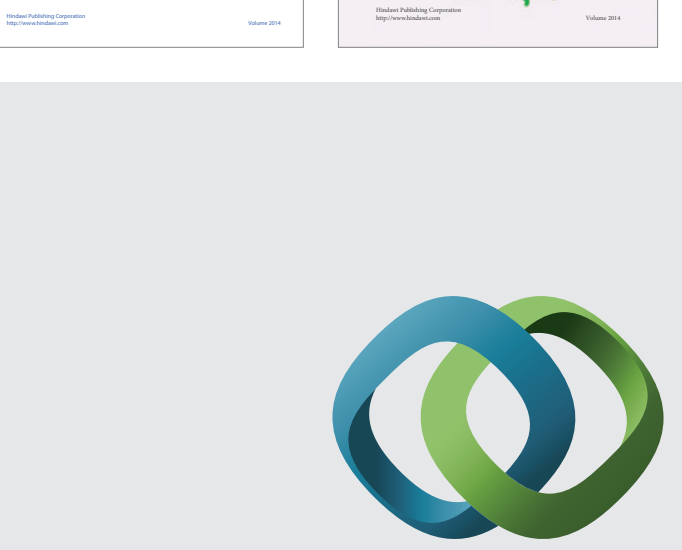

\section{Hindawi}

Submit your manuscripts at

http://www.hindawi.com
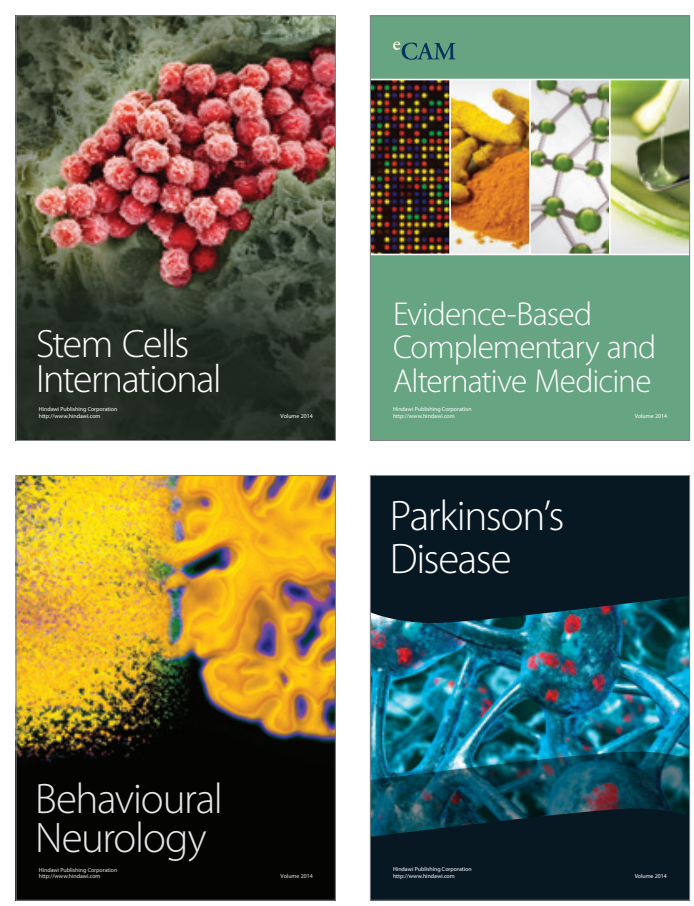

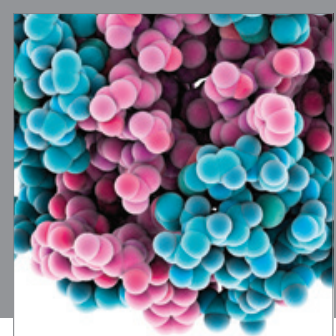

Journal of
Diabetes Research

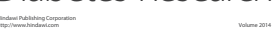

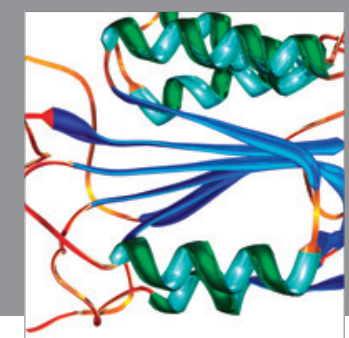

Disease Markers
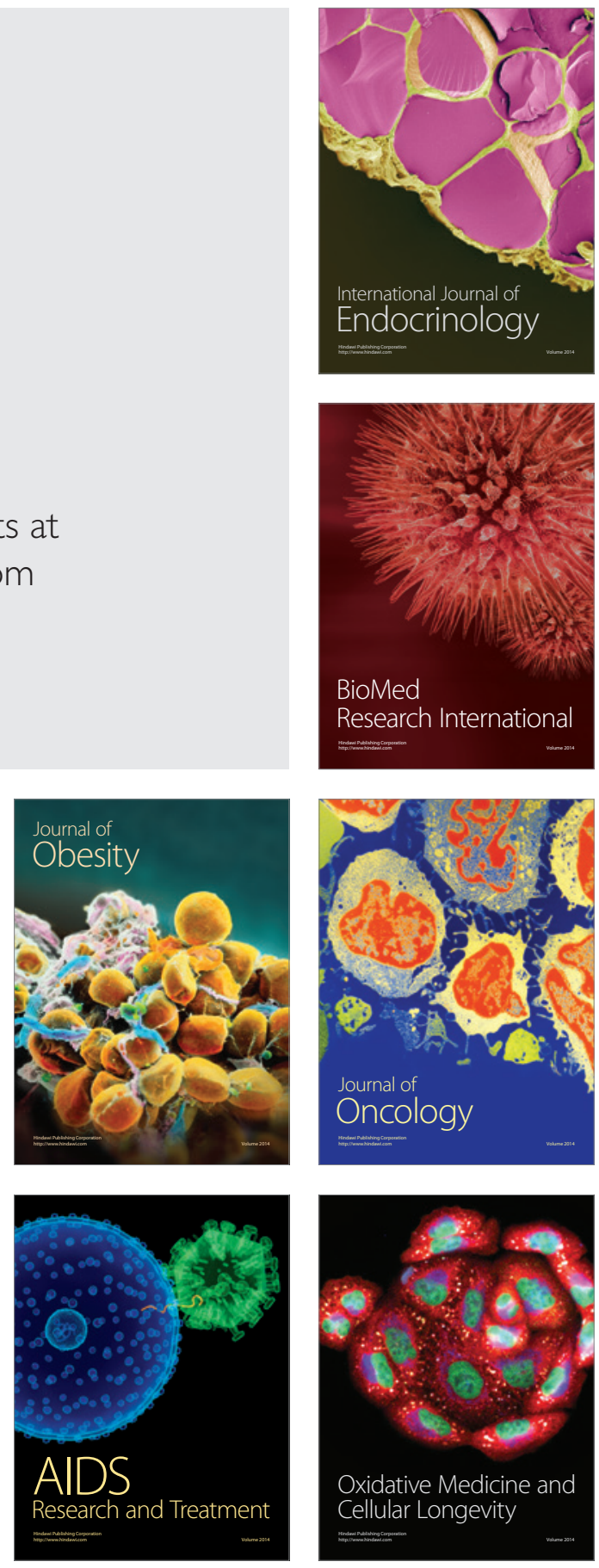